\title{
Obituary
}

\section{Dr. Yabuuti Kiyosi 薮内 清}

\author{
(1906-2000)
}

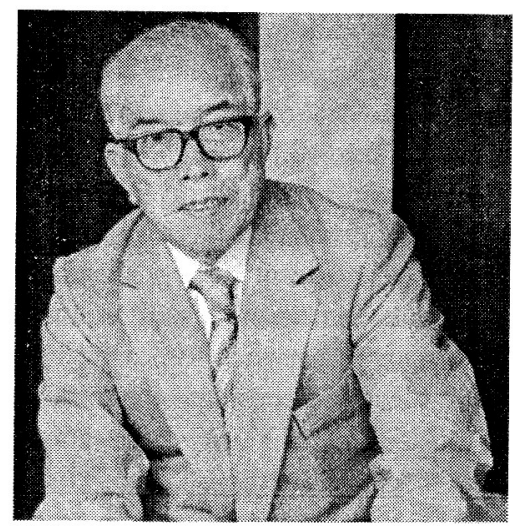

Courtesy of Mrs. Yabuuti Masa, the wife of the late Dr. Yabuuti Kiyosi

Professor Emeritus of Kyōto University, Dr. Yabuuti Kiyosi, who was a member of the Japan Academy, passed away in a hospital in Kyōto on June 2, 2000. He was 94 . He had been quite active until his last months, and had been very much pleased with the publication of the French version of his book Chügoku no sügaku中国の数学 (Chinese Mathematics) in Paris in February of this year. The great loss of our mentor in the field of the history of Chinese science and civilization is deeply felt by all of us.

Dr. Yabuuti was born in Kōbe on February 12, 1906. After completing the science class in French at the old Osaka High School, he matriculated at the Faculty of Science in the Imperial University of Kyōto in April 1926. There he studied astronomy and celestial mechanics. The future Nobel Laureates in Physics, Yukawa Hideki 湯川秀樹 and Tomonaga Shin'itirō 朝永振一郎, together with the mathematician Kobori Akira 小堀憲, also matriculated with him at the same university at that time. In the last year of the university course, he attended the lectures on the history of astronomy in East Asia delivered by Professor Shinjō Shinzō 新城新藏, who was to be appointed Chancellor of the University and later director of the Institute of Natural Science in Shanghai. Yabuuti himself became a research associate of the University immediately after his graduation. 
In April 1935, Dr. Yabuuti was made a research associate at the Kyōto Branch of the Institute of Eastern Culture (Tōhō bunka gakuin Kyōto kenkyūjo 東方文化学院京都研究所), established in 1929, later renamed as the Research Institute for Eastern Culture (Tōhō bunka kenkyūjo 東方文化研究所). Dr. Nōda Tadasuke 能田忠亮, well known for his studies on the Zhoubi suanjing 周髀算経, was Director of the Department of Chinese Astronomy and Calendrical Studies there. Yabuuti pursued the study of classical Chinese and Chinese linguistics in addition to his investigations into the history of astronomy in China. The first research topic to which he was assigned was the investigation of the star catalogue resulting from observations undertaken during the Huangyou 皇祐 reign-period of the Song Dynasty. It was on the basis of these observational results that the Suzhou Star Map (Suzhou tianwentu 蘇州天文図) of 1247 was produced.

Yabuuti tried to identify every star in the Huangyou star catalogue as preserved in the Songshi 宋史 (History of the Song Dynasty). He did this by making use of Tsuchihashi Yachita's 土橋八千太 work on Ignatius Kögler's Yixiang kaocheng 儀象考成 (An Examination into the Imperial Astronomical Instruments) of 1761. It was tough work, as he later recollected. His efforts resulted in the publication of the article 'Sōdai no seishuku'「宋代の星宿」[A Star Catalogue of the Song Dynasty] in 1936. He then turned to the earliest extant Chinese star catalogue, the Shishi xingjing 石氏星経. This had been preserved by the monk Gautama Siddharta during the Tang Dynasty in the Kaiyuan zhanjing 開元占経 (The Kaiyuan reign-period Treatise on Astrology [and Astronomy]). The results of these studies were published in 'Sekishi seikei no kenkyū'「石氏星経の研究」(Research on Mr. Siddharta's Star Catalogue), collected later in Chügoku no tenmon rekihō 中国の天文暦法 (Astronomy and Calendrical Methods in China) published in 1969 and revised in 1990.

Dr. Yabuuti concluded in this study that systematic observation for this earliest star catalogue had been carried out in about 70 BC. Moreover, he discovered that the stellar coordinates were given using "polar latitude," a practice also found in Indian astronomical systems. In fact, he found out that Indian stellar positions exactly corresponded to those in the Chinese data as analyzed by him. This was a great discovery concerning the history of Chinese astronomy. It not only showed that the Shishi xingjing is the oldest extant star catalogue, but also that, from an early time, China had a close relationship with India as far as astronomy was concerned. The importance that he attached to this crucial discovery can be seen from the fact that in his last lecture at Kyōto University he once again returned to this topic.

The next stage of his studies in the history of Chinese astronomy was concerned with the development of the Chinese calendrical system up to the Tang Dynasty. It was a topic that required a great deal of analytical research. His efforts culminated in the Zuitō rekihōshi no kenkyū 隋者暦法史の研究 (Research on the History of Calendrical Methods in the Sui and Tang Dynasties) of 1944, for which a Doctorate (of Science) was conferred on him by Kyōto 
University. In this work, he first surveyed the history of the Chinese calendar, and then critically examined the descriptions of calendrical systems as recorded in the Lïlizhi 律歴志 (Monograph on Mathematical Harmonics and the Calendar) of the Suishu 隋書 (History of the Sui Dynasty) and the Lizhi (Monograph on the Calendar) of the Tangshu 患書 (History of the Tang Dynasty). By mathematically analyzing the Huangji 皇極 calendrical system of the Sui period and the Linde 麟徳 and Dayan 大衍 calendrical systems of the early Tang period, he discovered that interpolation methods had been introduced in these calendars. This demonstrated that during these periods the Chinese calendar, i.e. the Iuni-solar calendrical system, had developed substantially. These research achievements have also been collected in Chügoku no tenmon rekihö (Astronomy and Calendrical Methods in China). It was mainly for this contribution that he was awarded the Asahi Cultural Prize later in 1970.

During the last year of the Second World War much of his energy was dedicated to rescuing the difficult situation the Institute was in. Indeed, the Institute was scheduled for closure at one point in 1945. Dr. Yabuuti went to Tōkyō several times to appeal to the Wartime government not to cut the financial resources of the Institute, and eventually, thanks largely to his efforts, the crisis was averted. In 1948, the Institute became one section, the Tōhōbu 東方部, the Department of Oriental Studies of the newly constituted Research Institute for $\mathrm{Hu}$ manities (Jimbun-kagaku kenkyūsho 人文科学研究所) of Kyōto University (Kyōto Daigaku 京都大学).

Alongside the continuation of individual research projects, collaborative work played an important role in this new Institute. Nōda and Yabuuti worked together on the Liilizhi chapter (Monograph on Mathematical Harmonics and the Calendar) of the Hanshu (History of the Han Dynasty) and, as a result of their studies, published the Kanjo ritsurekishi no kenkyu 漠書律暦志の研究 (Research on the "Monograph on Mathematical Harmonics and the Calendar") in 1947. Now, as professor of the History of Science Department in the Institute, Dr. Yabuuti started to bring together not only historians of science and technology, but also specialists in linguistics and Chinese history proper to work on Song Yingxing's Tiangong kaiwu 天工開物 (Exploitation of the Works of Nature). This monumental collaborative achievement resulted in the publication of the Tenko kaibutsu no kenkyü 天工開物の研究 (Research on the "Exploitation of the Works of Nature") in 1953. Immediately after this, the group started to do research on traditional industrial technology still surviving in Kyōto and its vicinity. These surveys of the skills of the craftsmen and examination of their production materials also proved to be very successful, and helped to make the late Professor Yoshida Mitsukuni 吉用光邦 an eminent specialist in this field.

As a next step, Professor Yabuuti and his research team started to work on the whole history of science and technology in China, from antiquity to the early modern period. This collaborative work produced a remarkable series of publications covering mathematics, science, medicine and technology. They included: a special issue on Chinese science in antiquity in Tóhō gakuhō, vol. 30, in 1959, 
Chügoku chūsei kagaku-gijutsushi no kenkyū 中国中世科学技術史の研究 (Studies on the Science and Technology of China in the Middle Ages) in 1963, Sō-Gen-jidai no kagaku-gijutsushi 宋元時代の科学技術史 (The History of Science and Technology in Song and Yuan China) in 1967, and Min-Shin-jidai no kagaku-gijutsushi 明清時代の科学技術史 (The History of Science and Technology in Ming and Qing China) in 1970.

During this period, his own work was also directed towards the whole range of Chinese sciences as well as to the respective Japanese, Korean, Indian, Greek and European endeavours and achievements. He was very much interested in cultural exchanges between these civilizations, thus clearly demonstrating his cross-cultural perspective. The total product of his research efforts amounted to well over three hundred books and articles. One cannot help but admire his great productivity. It is no wonder that people sometimes compared him with late Joseph Needham.

Needham was just one of Dr. Yabuuti's numerous friends from overseas, many of whom visited him in Kyōto. In fact, he eventually supervised the Japanese translation of Volumes 1 to 4 of Science and Civilisation in China, published under the title Chügoku no kagaku to bummei 中国の科学と文明 from 1974 onward. Lynn White Jr. visited him in 1971, and the following year, in 1972, he was awarded the George Sarton Medal. Other eminent friends among the international scholarly community included Willy Hartner, Edward S. Kennedy, Nathan Sivin, Jeon Sang Woon, Xi Zezong, Du Shiran, Ho Peng Yoke, Christopher Cullen, and many others.

Dr. Yabuuti was also very active in organizing domestic and international conferences. He was chairman of the organizing committee of the XIV International Congress of the History of Science, held in Tōkyō and Kyōto, in 1974. The Japan-Korea Exchange Seminars on the History of Science were sometimes held in Kyōto. In addition, the Research Institute for Humanities, Kyōto University, held the International Symposium on the History of Chinese Science (Chūgoku kagakushi kokusai kaigi 中国科学史国際会議) for him in 1987. We also feel very proud that in 1993 we were able to hold the $7^{\text {th }}$ International Conference on the History of Science in East Asia in Kyōto in honour of Dr. Yabuuti, then 88 years old.

Dr. Yabuuti was awarded the status of Emeritus Professor by Kyōto University on his retirement in 1969. Immediately thereafter, he was made professor at Ryūkoku University for ten years. Furthermore, he was awarded the Purple Ribbon Medal in 1970, and was conferred the rank of Second Order of the Sacred Treasure Kun-nitō Zuihōshō 勲二等瑞宝章 for his life-long academic achievement in 1979. He delivered a lecture on Chinese astronomy and calendrical methods in the presence of the Emperor at the ceremony of the "Beginning of the Interpretation of the Texts" at the Palace in 1979. And, in 1983, he joined the prestigious Japan Academy. Attending the regular meetings there in Tōkyō was Professor Yabuuti's great pleasure in his later years. In 1988 Asteroid 2652 was named after Professor Yabuuti, a tribute to his pioneering studies of ancient Chi- 
nese astronomy. He was made Honorary Professor by the Institute of the History of Natural Sciences, Chinese Academy of Sciences, Beijing.

I should like to end by expressing my sincere gratitude and appreciation for his constant encouragement which guided all of us who followed in his footsteps. Dr. Yabuuti was given the Buddhist name Shaku Shōjō 釈 清浄(Pure and Clean). Let us press our hands together in prayer, gasshō 合掌.

Hashimoto Keizo 